\title{
Lowering treatment temperature reduces salmon mortality: a new way to treat with hydrogen peroxide in aquaculture
}

\author{
Kathy Overton ${ }^{a^{*}}$, Francisca Samsing ${ }^{a}$, Frode Oppedal ${ }^{b}$, Lars H Stien ${ }^{b}$, Tim Dempster ${ }^{a}$ \\ a Sustainable Aquaculture Laboratory - Temperate and Tropical (SALTT), School of \\ BioSciences, University of Melbourne, Parkville VIC 3010, Australia \\ ${ }^{b}$ Institute of Marine Research, P.O. Box 1870, 5817 Bergen, Norway \\ *Corresponding author: Kathy Overton \\ Email: koverton@student.unimelb.edu.au \\ Running title: Modifying temperature during $\mathrm{H}_{2} \mathrm{O}_{2}$ treatment reduces salmon mortality
}

\begin{abstract}
BACKGROUND

Hydrogen peroxide $\left(\mathrm{H}_{2} \mathrm{O}_{2}\right)$ baths are widely used to reduce salmon lice on farmed Atlantic salmon. Fish mortalities often occur after baths, with warmer temperatures increasing lethality. We tested if mortality could be reduced and lice removal efficacy maintained by lowering bath temperatures relative to ambient temperatures. Post-smolt salmon infected with lice were held at 10,13 or $16^{\circ} \mathrm{C}$, and treated with $1.5 \mathrm{~g} \mathrm{~L}^{-1} \mathrm{H}_{2} \mathrm{O}_{2}$ for 20 minutes at equal or lower bath temperatures of 7,10 or $13^{\circ} \mathrm{C}$.
\end{abstract}

This is the author manuscript accepted for publication and has undergone full peer review but has not been through the copyediting, typesetting, pagination and proofreading process, which may lead to differences between this version and the Version of Record. Please cite this article as doi: $10.1002 / p s .4751$

This article is protected by copyright. All rights reserved. 


\section{RESULTS}

Salmon mortality decreased as ambient and bath temperatures decreased. No mortality occurred when fish at $13^{\circ} \mathrm{C}$ were treated at $7^{\circ} \mathrm{C}$. For ambient temperatures of $16^{\circ} \mathrm{C}$, lice remaining was reduced by 4 times when treated at $7^{\circ} \mathrm{C}$ compared to $13^{\circ} \mathrm{C}$. All treatments where mortality was zero had similar efficacies regardless of bath temperature.

\section{CONCLUSION}

We took salmon from warmer to colder temperatures to determine the optimum bathing temperature to prevent mortality. $7^{\circ} \mathrm{C}$ was optimal when treating with $1.5 \mathrm{~g} \mathrm{~L}^{-1}$ of $\mathrm{H}_{2} \mathrm{O}_{2}$, as mortality was nil and pre-adult lice removal was unchanged. By manipulating temperature, we developed a new method of $\mathrm{H}_{2} \mathrm{O}_{2}$ bathing that reduces mortality. When ambient temperatures $>10^{\circ} \mathrm{C}$, we recommend that the industry decrease $\mathrm{H}_{2} \mathrm{O}_{2}$ bath temperatures.

\section{Keywords}

AQUACULTURE, CONTROL, HYDROGEN PEROXIDE, PARASITE, SALMO SALAR

This article is protected by copyright. All rights reserved. 
Headings

1. Introduction

2. Materials and methods

2.1 Study location and animals

2.2 Lice infestation

2.3 Experimental design and procedures

2.4 Mortality

2.5 Pre-adult lice removal

2.6 Frequency of treatment temperature and month from 2012-2017

2.7 Statistical analysis

3. Results

3.1 Mortality

3.2 Pre-adult lice remaining

3.3. Frequency of treatment temperature and month from 2012-2017

4. Discussion

4.1 Mortality

4.2 Pre-adult lice remaining

4.3 Industry relevance

4.4 Feasibility

5. Conclusion 


\section{Introduction}

The ecotoparasitic salmon louse (Lepeophtheirus salmonis) is the most problematic parasite for the Atlantic salmon (Salmo salar) farming industry globally, and hinders the growth of the industry. ${ }^{1}$ They not only have a greater economic impact than any other parasite, but also represent a risk to wild salmonid populations due to transmission from farmed populations. ${ }^{2,3}$ Negative impacts of lice on salmon include increased stress, skin damage from feeding, reduced swimming performance and osmoregulatory failure. ${ }^{4,2,3}$

The farming industry reduces the impacts of salmon lice through a diverse range of control and prevention methods. ${ }^{5,6}$ Chemotherapeutants are the most common method of control, however their efficacies are declining due to the rapid evolution of resistance towards them. ${ }^{7,8}$ Loss of efficacy of a range of chemotherapeutants led to the re-introduction of hydrogen peroxide $\left(\mathrm{H}_{2} \mathrm{O}_{2}\right)$ as a delousing agent in Norway in 2009. Whilst the exact mechanism of lice removal by $\mathrm{H}_{2} \mathrm{O}_{2}$ is unknown, it is thought that gas bubbles develop in the louse's haemolymph, making it unable to hold onto the surface of the salmon and fall off. 7,9

On salmon farms, $\mathrm{H}_{2} \mathrm{O}_{2}$ treatments are administered in two different ways. Both methods start by lifting the cage floor to crowd the fish. The first method then encloses the lifted sea cage with a tarpaulin. An initial dose is administered, and it takes approximately 10 minutes to determine the concentration before the full dose is administered at a concentration between 1.3 and $1.8 \mathrm{~g} \mathrm{~L}^{-1}$ for 20-30 minutes (Overton $\mathrm{K}, 2017$, pers. comm.). The second 
method is through the use of well-boats. The crowded fish are vacuum pumped and gravity transported through a pipe line to a well-boat filled with seawater. ${ }^{10} \mathrm{~A}$ low dose of $\mathrm{H}_{2} \mathrm{O}_{2}$ is then administered, and the initial concentration in the well is calculated. This takes approximately 10 minutes (Overton $\mathrm{K}, 2017$, pers. comm.). After the initial concentration is calculated, the dose is increased to a concentration between 1.3 and $1.8 \mathrm{~g} \mathrm{~L}^{-1}$ and the fish are treated for 20-30 minutes. The unloading process from a well-boat into sea-cages involves water level reduction within the well, crowding and vacuum-pumping. ${ }^{10}$ $\mathrm{H}_{2} \mathrm{O}_{2}$ use in the Norwegian industry flourished after its reintroduction, reaching a peak in 2015 with 43,246 tonnes used (Fig. 1;). ${ }^{11}$ However, the volume used by the Norwegian industry decreased by $42 \%$ from 2015 to 2016 . This recent decline is due to its impacts on salmon and increased louse resistance to $\mathrm{H}_{2} \mathrm{O}_{2}$.

$\mathrm{H}_{2} \mathrm{O}_{2}$ treatment can negatively impact salmon. Individuals may show signs of respiratory distress during treatment and lethargy afterwards. ${ }^{12}$ Treatment can also increase stress, illustrated through elevated plasma glucose, cortisol and electrolyte levels. ${ }^{13}$ The toxicity of $\mathrm{H}_{2} \mathrm{O}_{2}$ to salmon increases with temperature, especially above $14^{\circ} \mathrm{C}$, and high salmon mortalities are associated with high treatment temperatures. ${ }^{13,9}$ Large scale mortality events have occurred shortly after $\mathrm{H}_{2} \mathrm{O}_{2}$ treatments, especially during the summer. For example, 143,199 salmon died after $\mathrm{H}_{2} \mathrm{O}_{2}$ treatment at three sites in $2016 .{ }^{15}$ The underlying 
cause of such high mortalities is unknown, but is suspected to be linked to water temperatures during treatment.

Parasite resistance towards $\mathrm{H}_{2} \mathrm{O}_{2}$ treatment has started to spread throughout Norway. ${ }^{16}$ Hence, treatment efficacy in these areas has decreased, which could partly explain decreased usage of $\mathrm{H}_{2} \mathrm{O}_{2}$ in 2016. Continual usage of $\mathrm{H}_{2} \mathrm{O}_{2}$ in these areas will potentially become more ineffective, and may lead to more surviving adult lice which are then able to pass on genes for resistance to offspring. ${ }^{16}$ If $\mathrm{H}_{2} \mathrm{O}_{2}$ use is to continue to be effective, treatments must leave little to no survivors.

Both the negative impacts from treatment and the evolution of resistance towards $\mathrm{H}_{2} \mathrm{O}_{2}$ could explain why there was such a substantial decrease in $\mathrm{H}_{2} \mathrm{O}_{2}$ usage in 2016 (Fig. 1). The way the Norwegian industry treats salmon with $\mathrm{H}_{2} \mathrm{O}_{2}$ must be improved to reduce these negative impacts. A possible solution to improve both these issues could be to decrease seawater temperature during $\mathrm{H}_{2} \mathrm{O}_{2}$ treatment. We hypothesise that by decreasing bath temperature, the negative effects of $\mathrm{H}_{2} \mathrm{O}_{2}$ treatment on salmon would be minimized and salmon mortality would in turn be lowered. However, due to $\mathrm{H}_{2} \mathrm{O}_{2}$ efficacy decreasing at lower temperatures, ${ }^{17}$ the optimal bath temperature needs to be determined to minimize mortality while maximising lice removal.

This article is protected by copyright. All rights reserved. 
Here, we aimed to determine how lowering the bath temperature during $\mathrm{H}_{2} \mathrm{O}_{2}$ treatment may influence mortality of salmon and efficiency of removing pre-adult lice. To simulate a well-boat treatment in laboratory conditions, we designed an experiment that stressed salmon immediately before treatment (netting representing crowding and vacuumpumping) and flushing after treatment was over. We had eight treatment groups: each treatment had an ambient (pre-bath and post-bath) water temperature of either 10, 13 or $16^{\circ} \mathrm{C}$, and a bath temperature of either 7,10 or $13^{\circ} \mathrm{C}$. This novel method of treating with $\mathrm{H}_{2} \mathrm{O}_{2}$ aims to reduce salmon mortality by reducing bath treatment temperature.

\section{Materials and methods}

\subsection{Study location and animals}

The experiment was conducted at the Matre Research Station of the Institute of Marine Research (IMR), Norway. To test the effect of lowering water temperature during $\mathrm{H}_{2} \mathrm{O}_{2}$ treatment on salmon mortality and lice removal, eight treatments were used. Post-smolt Atlantic salmon sourced from stocks held at IMR (Aquagen strain) were used with a weight of $288 \pm 3 \mathrm{~g}$ (mean \pm S.E.) and fork length of $30 \pm 1 \mathrm{~cm}$ (mean \pm S.E.). Forty fish were randomly allocated into 8 tanks $\left(0.9 \mathrm{~m} \times 0.9 \mathrm{~m} \times 0.4 \mathrm{~m} \approx 0.32 \mathrm{~m}^{3}\right)$ with water flow at $12 \mathrm{~L}$ $\min ^{-1}$ and $16^{\circ} \mathrm{C}$ throughout lice infestation.

This article is protected by copyright. All rights reserved. 


\subsection{Lice infestation}

Salmon lice were collected from salmon in sea-cages at a salmon farm in Austevoll on $8 / 02 / 2017$. Austevoll lies in an area of intensive salmon production with multiple farms closely connected, ${ }^{18}$ which means that our lice population has been exposed to multiple treatment methods through time. Egg string pairs were collected from adult female lice on anesthetized fish (metomidate $10 \mathrm{mg} \mathrm{L}^{-1}$ ). Egg strings were incubated at $10^{\circ} \mathrm{C}$ until the infective planktonic copepodid stage was reached. 30 copepodids per fish were used for infection.

Each of the eight treatment tanks were infected on the same day at $16^{\circ} \mathrm{C}$. The water flow in each tank was reduced to $3 \mathrm{~L} \mathrm{~min}^{-1}$ prior to infection and the water level within the tanks were lowered to a depth of $15 \mathrm{~cm}$. Copepodids were left in the tanks for 45 minutes to infect the fish. Fish were disturbed every ten minutes to prevent them from resting at the bottom of the tank and ensure they were swimming. After 45 minutes, water flows within tanks were turned back up to $12 \mathrm{~L} \mathrm{~min}^{-1}$.

Experimental tanks were used to hold the fish for approximately two weeks during lice infection and until the lice reached pre-adult stages following Stien et al. ${ }^{19}$ This ensured that lice infection was the same for all fish. By adjusting temperatures after infection, we staggered the growth of lice to ensure that lice were all at the same life cycle stage during subsequent $\mathrm{H}_{2} \mathrm{O}_{2}$ treatment. All tanks receiving water at the ambient temperatures of $16^{\circ} \mathrm{C}$ 
were maintained for 10 days until lice reached the pre-adult I stage. Water temperature was decreased from $16^{\circ} \mathrm{C}$ to $13^{\circ} \mathrm{C}$ an hour post-infection for tanks receiving water at an ambient temperature of $13^{\circ} \mathrm{C}$ and $10^{\circ} \mathrm{C}$. Tanks receiving ambient water at $13^{\circ} \mathrm{C}$ were maintained for 13 days until lice reached pre-adult I stage. Tanks receiving ambient water at $10^{\circ} \mathrm{C}$ were maintained at $13^{\circ} \mathrm{C}$ for 7 days before further lowering to $10^{\circ} \mathrm{C}$ for another 9 days until lice had developed to the pre-adult I stage.

During lice development, fish were kept at salinity $34 \%$ and dissolved oxygen concentration above $90 \%$ air saturation. Tanks were continuously illuminated (24:0 L:D regime) and fish were continuously fed to satiation (2-3 mm pellets, Skretting, Norway), except $24 \mathrm{~h}$ before $\mathrm{H}_{2} \mathrm{O}_{2}$ treatment and sampling.

\subsection{Experimental design and procedures}

Eight ambient bath temperature and bath combinations, represented by $A-B-A^{\circ} \mathrm{C}(A=$ ambient and $\mathrm{B}=$ bath) were used to test if temperature change and $\mathrm{H}_{2} \mathrm{O}_{2}$ treatment influenced salmon mortality and lice removal efficacy (Table 1). A total of 320 fish were used; 8 treatment temperature groups (A-B-A) performed in triplicate $(n=3)$ with 10 fish per replicate, plus 80 fish used for a pre-treatment sample to assess lice counts (10 fish per treatment temperature group). The individuals were treated with $1.5 \mathrm{~g} \mathrm{~L}^{-1}$ of $\mathrm{H}_{2} \mathrm{O}_{2}$ for 20 minutes in all treatments. The unit of replication used throughout all experimentation was 
individual experimental tanks. Three tanks $\left(0.9 \mathrm{~m} \times 0.9 \mathrm{~m} \times 0.4 \mathrm{~m} \approx 0.32 \mathrm{~m}^{3}\right)$ were used during $\mathrm{H}_{2} \mathrm{O}_{2}$ treatments for each replicate per treatment temperature group.

On the day of $\mathrm{H}_{2} \mathrm{O}_{2}$ treatment, experimental $\mathrm{H}_{2} \mathrm{O}_{2}$ treatment tanks were prepared by filling all three tanks with seawater at the bath temperature. The water level in each tank was measured to ensure that all tanks had a depth of $30 \mathrm{~cm}$. Water flow was turned off during treatment, and a recirculation pump was used to provide a controlled and even circulation of $\mathrm{H}_{2} \mathrm{O}_{2}$ throughout the tank. Ten fish from the holding tank were randomly allocated into a treatment tank using a net. After all 10 fish were placed into a treatment tank, $\mathrm{H}_{2} \mathrm{O}_{2}$ (Hydrogen peroxide $49.5 \%$, Chemco As, Norway) was poured through a funnel directly in front of the recirculation pump. After 20 minutes, $\mathrm{H}_{2} \mathrm{O}_{2}$ was flushed out of the tanks by reducing the water level and rapidly increasing water inflow $\left(30 \mathrm{~L} \mathrm{~min}^{-1}\right)$. Tanks were flushed for 5 minutes using water at the ambient temperature.

\subsection{Mortality}

Six hours after treatment, mortalities in each experimental replicate tank were recorded and carcasses removed.

\subsection{Pre-adult lice removal}

To determine the number of pre-adult lice before $\mathrm{H}_{2} \mathrm{O}_{2}$ treatment, the remaining 10 fish in the holding tanks were removed, euthanized and immediately placed in individual sampling 
bags to prevent lice loss. The weight $(\mathrm{g})$, fork length $(\mathrm{cm})$ and number of pre-adult lice on each fish was recorded.

Six hours after $\mathrm{H}_{2} \mathrm{O}_{2}$ treatment, the surviving fish in each experimental treatment tank were removed, euthanized and placed within individual sampling bags. The weight and fork length of each fish as well as the number of pre-adult lice on them were recorded.

\subsection{Frequency of $\mathrm{H}_{2} \mathrm{O}_{2}$ treatment temperature and month from 2012-2017}

Using a database on 545 salmon lice removal treatments that were reported to the Norwegian Directorate of Fisheries from 2012-April 2017, we assessed the frequencies of $\mathrm{H}_{2} \mathrm{O}_{2}$ treatment by temperature and month. Treatment temperatures ranged from $4-17^{\circ} \mathrm{C}$.

\subsection{Statistical analysis}

The salmon mortality dataset was dominated by a high number of zeros. Therefore, deviance in salmon mortality among treatments was modelled using a zero-inflated count regression model ( $R$, package pscl, function zeroinfl). There was no interaction between ambient temperature and bath temperature (chi-squared test; $p=0.15$ ). The normality of errors and variance homogeneity was confirmed using model checking plots.

To test if differences existed among treatments in the percentage of pre-adult lice that survived after bath treatments, we used a one-way ANOVA, with a post-hoc Tukey's test. 
The normality of errors and variance homogeneity was confirmed using model checking plots.

\section{Results}

\subsection{Mortality}

Overall, as ambient and bath temperature decreased, salmon mortality also decreased $(z=$ $2.5, p=0.01 ; t=3.5, p=0.0005 ;$ respectively) (Fig. $2 A)$. Salmon mortality was highest in the treatment $16-13-16^{\circ} \mathrm{C}$, with a mortality of $50 \pm 25.2 \%$ (mean \pm S.E.). Mortality in this treatment was 4 times higher compared to the other two treatment groups with the same ambient temperature but lower bath temperatures $\left(10^{\circ} \mathrm{C}\right.$ and $\left.7^{\circ} \mathrm{C}\right)$. Within the treatments with ambient temperatures of $13^{\circ} \mathrm{C}$, there was a clear reduction of mortality as bath temperature decreased. When ambient temperature and bath temperatures were $13^{\circ} \mathrm{C}$, mortalities were highest at $27 \pm 14.5 \%$ (mean \pm S.E.). However, mortality halved with a $3^{\circ} \mathrm{C}$ reduction in bath temperature to $10^{\circ} \mathrm{C}$ and was removed entirely with a $6^{\circ} \mathrm{C}$ reduction in bath temperature to $7^{\circ} \mathrm{C}$. No mortalities were observed for the treatments with ambient temperatures of $10^{\circ} \mathrm{C}$.

\subsection{Pre-adult lice remaining}

As ambient and bath temperatures decreased, pre-adult lice remaining after $\mathrm{H}_{2} \mathrm{O}_{2}$ treatment declined $(\mathrm{df}=7, \mathrm{~F}=3.3, \mathrm{p}=0.02 ;$ Fig. $2 \mathrm{~B})$. The mean pre-adult lice load for each fish was $7.51 \pm 0.3$ (mean $\pm \mathrm{SE}$ ). The $16-13-16^{\circ} \mathrm{C}$ treatment was highly ineffective, with 
almost $50 \%$ of pre-adult lice surviving. By comparison, surviving lice were almost 4 times lower in the $16-10-16^{\circ} \mathrm{C}$ treatment $(p=0.04)$, with $16 \pm 2.4 \%$ (mean \pm S.E.) surviving. The $13-$ $13-13^{\circ} \mathrm{C}$ treatment also had nearly 4 times more lice surviving compared to $16-10-16^{\circ} \mathrm{C}(\mathrm{p}=$ 0.04). All treatments with ambient temperatures of $13^{\circ} \mathrm{C}$ and $10^{\circ} \mathrm{C}$ had between $26-44 \%$ lice surviving, with no differences detected between treatments, regardless of bath temperature.

\subsection{Frequency of treatment temperature and month from 2012-2017}

An analysis of $\mathrm{H}_{2} \mathrm{O}_{2}$ use in the Norwegian industry database revealed that $7^{\circ} \mathrm{C}$ was the most common treatment temperature (25\%), followed by $6^{\circ} \mathrm{C}$ (13\%; Fig. $3 \mathrm{~A}$ ). $14.4 \%$ of $\mathrm{H}_{2} \mathrm{O}_{2}$ treatments were performed at bath temperatures of $13^{\circ} \mathrm{C}$ and above and $40 \%$ of all treatments were performed at $10^{\circ} \mathrm{C}$ and above (Fig. 3A).

$\mathrm{H}_{2} \mathrm{O}_{2}$ treatments were performed year-round, with the most treatments executed in November (16\%), and the least in September (3\%; Fig. 3B). Winter months (December February) had higher treatment frequencies (31\%) compared to summer months (June August) (15\%).

\section{Discussion}

\subsection{Mortality}

This article is protected by copyright. All rights reserved. 
Our results illustrate a distinct reduction in salmon mortality as both ambient and bath temperature decrease. Acute lethal toxicity of $\mathrm{H}_{2} \mathrm{O}_{2}$ increases with exposure time, $\mathrm{H}_{2} \mathrm{O}_{2}$ dosage and temperature. ${ }^{9}$ Salmon mortality likely occurs through gill damage caused by exposure to $\mathrm{H}_{2} \mathrm{O}_{2}$, which increases with temperature and $\mathrm{H}_{2} \mathrm{O}_{2}$ dose. ${ }^{20}$ When we held exposure time and $\mathrm{H}_{2} \mathrm{O}_{2}$ dose constant for all treatments, reduced ambient and bath temperatures led to lower salmon mortality.

We took salmon from warmer to colder temperature conditions in search of temperatures where treatment could occur and no mortality result. While the importance of treatment temperature is already well established, we did not know how well salmon would respond to instantaneous temperature change prior to treatment. Our results identify a new method: the industry can manipulate $\mathrm{H}_{2} \mathrm{O}_{2}$ bath temperatures to substantially reduce mortalities from treatments. Salmon mortality decreased by 4 times when fish at $16^{\circ} \mathrm{C}$ were treated at $10^{\circ} \mathrm{C}$, and mortality was eliminated when fish at $13^{\circ} \mathrm{C}$ were treated at $7^{\circ} \mathrm{C}$. As $40 \%$ of all $\mathrm{H}_{2} \mathrm{O}_{2}$ bath treatments in Norway from 2012-2016 were made at temperatures $>10^{\circ} \mathrm{C}$ (Fig. 3A), these results are relevant, particularly given the extensive mortalities after $\mathrm{H}_{2} \mathrm{O}_{2}$ treatments identified in analyses of the Norwegian databases on treatments and mortalities. $^{21}$

\subsection{Pre-adult lice remaining}

This article is protected by copyright. All rights reserved. 
When ambient temperatures were high, we achieved marked improvements in efficiency of lice removal by decreasing bath treatment temperatures. Lice removal was worst in the 16$13-16^{\circ} \mathrm{C}$ treatment, and more than 4 times more effective in the $16-10-16^{\circ} \mathrm{C}$ treatment. Likewise, lice removal was low in the $13-13-13^{\circ} \mathrm{C}$ treatment and twice as effective in the $13-$ $10-13^{\circ} \mathrm{C}$ treatment. This suggests that instantaneous temperature change combined with $\mathrm{H}_{2} \mathrm{O}_{2}$ application could have reduced the ability of lice to remain attached to the skin of the salmon. This effect may only exist at higher temperatures, as we did not see a similar reduction at ambient temperatures of $10^{\circ} \mathrm{C}$.

We did not detect any differences in pre-adults remaining among treatments where mortality levels were zero (with ambient temperatures of $13^{\circ} \mathrm{C}$ and $10^{\circ} \mathrm{C}$ ). In general, lower $\mathrm{H}_{2} \mathrm{O}_{2}$ bath temperatures decrease efficacy and lead to a greater percentage of surviving preadult lice. ${ }^{14,17}$ During treatment, prescribing veterinarians can control treatment dose and duration, which has significant bearing on lice removal efficiency. ${ }^{14,22}$ If farmers were to lower $\mathrm{H}_{2} \mathrm{O}_{2}$ bath treatment temperatures, further testing should identify if a greater dose and/or duration of $\mathrm{H}_{2} \mathrm{O}_{2}$ than used here $\left(1.5 \mathrm{~g} \mathrm{~L}^{-1}\right.$ for 20 minutes) would increase efficiency of lice removal, while maintaining zero mortality. Further, we suggest that our reduced temperature $\mathrm{H}_{2} \mathrm{O}_{2}$ treatment should be used in conjunction with other lice management strategies, such as cleaner fish to remove any surviving lice. ${ }^{23}$

This article is protected by copyright. All rights reserved. 
Overall, salmon lice removal was only partially effective, which concurs with existing evidence for the evolution of resistance by lice towards $\mathrm{H}_{2} \mathrm{O}_{2} \cdot{ }^{16}$ Egg strings used to produce lice were collected from adult females infecting salmon on a farm in an area (Austevoll) with intensive salmon farming. $A$ test based on gene expression correlating with $\mathrm{H}_{2} \mathrm{O}_{2}$ resistance in the lice population at this site showed a $67 \%$ treatment effect calculated from the probability of lice becoming immobilized after $\mathrm{H}_{2} \mathrm{O}_{2}$ (LiceAdvisor, Report Code: PG028800 test performed 23/12/2016). The mean efficacy across all eight treatments of pre-adult lice surviving after $\mathrm{H}_{2} \mathrm{O}_{2}$ bathing was $32 \pm 3 \%$ (mean $\pm \mathrm{SE}$ ). Therefore, lice used in our experiment were likely sourced from a population that carried resistance genes.

\subsection{Industry relevance}

Previous studies have routinely recommended that $\mathrm{H}_{2} \mathrm{O}_{2}$ treatments should not be performed at temperatures above $13-14^{\circ} \mathrm{C}$ due to its acute toxicity to salmon. ${ }^{20,14,9} \mathrm{We}$ recorded $27 \%$ mortality on average when ambient and bath temperatures were $13^{\circ} \mathrm{C}$, which is an unacceptably high mortality, particularly if it occurred in industry-scale treatments. Our analysis of $\mathrm{H}_{2} \mathrm{O}_{2}$ usage in the Norwegian industry database illustrated more than $14.4 \%$ of $\mathrm{H}_{2} \mathrm{O}_{2}$ treatments were performed at $13^{\circ} \mathrm{C}$ and above, and that $40 \%$ of all treatments were performed at $10^{\circ} \mathrm{C}$ and above (Fig. 3A). Within this temperature range, the likelihood of lethal and sub-lethal effects of $\mathrm{H}_{2} \mathrm{O}_{2}$ treatment on salmon will be highest.

This article is protected by copyright. All rights reserved. 
Most $\mathrm{H}_{2} \mathrm{O}_{2}$ treatments in Norway are performed at temperatures $<10^{\circ} \mathrm{C}(>55 \%)$, with $7^{\circ} \mathrm{C}$ as the most common treatment temperature, most likely due to lower salmon mortality at this temperature. This correlates with seawater temperatures during the colder months, which explains why $\mathrm{H}_{2} \mathrm{O}_{2}$ treatments are used more frequently in the coldest months (NovemberMarch), with few used in summer and autumn (Fig. 3B). Our novel method of reducing bath temperature during $\mathrm{H}_{2} \mathrm{O}_{2}$ treatment to $7^{\circ} \mathrm{C}$ could therefore be applied to the industry to reduce salmon mortality, particularly in the summer and autumn months of JuneNovember.

Within each ambient temperature group (i.e. $16,13,10^{\circ} \mathrm{C}$ ), salmon mortality was low or eliminated when baths were made at $10^{\circ} \mathrm{C}$ or $7^{\circ} \mathrm{C}$ and treatment efficacy was similar at $10^{\circ} \mathrm{C}$ and $7^{\circ} \mathrm{C}$. The next step is to test if salmon mortality and lice removal efficacy hold with this method at full industrial scale. While our experiment was designed to simulate a well-boat treatment by stressing salmon immediately before treatment (netting representing vacuumpumping) and flushing after treatment was over, real world conditions may be different due to scale-dependent effects. Altered stress levels may result, which could alter the levels of the effects we determined at an experimental scale.

\subsection{Feasibility}

There are several methods to source colder seawater to treat salmon with $\mathrm{H}_{2} \mathrm{O}_{2}$. For treatments in well-boats, wells are filled with water and the salmon are transported via 
vacuum fish pumping. ${ }^{24}$ Therefore, cold seawater would already need to be in the wells before fish are pumped from cages. Three different methods could achieve this: 1) a pump could be used to pump seawater from a lower depth; 2) cold seawater could be sourced from a facility on land, which can fill the well prior to treatment; and 3) some well-boats are equipped with seawater chilling machines used to reduce the temperature of salmon before they are slaughtered. ${ }^{25}$ These machines could lower seawater temperature in the wells prior to treatment with $\mathrm{H}_{2} \mathrm{O}_{2}$.

\section{Conclusion}

$\mathrm{H}_{2} \mathrm{O}_{2}$ is still the primary chemical used for delousing within the Norwegian salmon aquaculture industry. While it is becoming more ineffective in areas where the evolution of resistance has been detected, the declining efficacies of alternate delousing chemotherapeutants means the industry will rely on it for some time to come. High salmon mortalities from treatment, particularly during summer, hinder production growth and efficiency. Therefore, our solution of transferring fish from $13-16^{\circ} \mathrm{C}$ seawater into $7^{\circ} \mathrm{C}$ baths will reduce mortalities whilst maximizing treatment efficacy. The method may also provide benefit at ambient temperatures between 10 and $13^{\circ} \mathrm{C}$.

$\mathrm{H}_{2} \mathrm{O}_{2}$ treatment in salmon aquaculture is used in several countries, such as Chile, UK, Canada and Ireland. ${ }^{26}$ Furthermore, it is used to bathe species other than salmonids to remove external parasites in saltwater (e.g. Seriola lalandi) ${ }^{27}$ and freshwater settings (walleye, 
bluegill channel catfish, yellow perch) ${ }^{28}$. In other species, mortality events through $\mathrm{H}_{2} \mathrm{O}_{2}$ use could be reduced or prevented by reducing the bath temperature during treatment.

Furthermore, our approach could be tailored to other treatments that may have temperature-dependent efficacy and effects on fish.

\section{Acknowledgements}

This project was funded by an Australian Research Council Future Fellowship (TD) and Research Council of Norway Project REGLICE \#244439 (FO, TD). We thank CHEMCO Inc. for supplying the hydrogen peroxide and staff at the Institute of Marine Research in Matre, especially Lise Dyrhovden and Karen Anita Kvestad. This research was approved by the FSA $\# 11436$.

This article is protected by copyright. All rights reserved. 


\section{References}

1 Mordue AJ and Birkett MA, A review of host finding behavior in the parasitic sea louse, Lepeophtheirus salmonis (Caligidae: Copepoda). J Fish Dis 32: 3-13 (2009).

2 Costello M J, Ecology of sea lice parasitic on farmed and wild fish. Trends Parasitol 22: 475483 (2006).

3 Torrissen O, Jones S, Asche F, Guttormsen A, Skillbrei OT, Nilsen F, Horsberg TE and Jackson D, Salmon lice - impact on wild salmonids and salmon aquaculture. J Fish Dis 36: 171-194 (2013).

4 Bowers JM, Mustafa A, Speare DJ, Conboy GA, Brimacombe M, Sims DE and Burka JF, The physiological response of Atlantic salmon, Salmo salar L., to a single experimental challenge with sea lice, Lepeophtheirus salmonis. J Fish Dis 23: 165-172 (2000).

5 Powell A, Treasurer JW, Pooley CL, Keay AJ and Lloyd R, Use of lumpfish for sea-lice control in salmon farming: challenges and opportunities. Rev Aquacult DOI: 10.1111/raq.12194 (2017).

6 Oppedal F, Samsing F, Dempster T, Wright DW, Bui S and Stien LH, Sea lice infestation levels decrease with deeper 'snorkel' barriers in Atlantic salmon sea-cages. Pest Manag Sci 73: 1935-1943 (2017).

7 Aaen SM, Helgesen KO, Bakke MJ, Kaur K and Horsberg TE, Drug resistance in sea lice: a threat to salmonid aquaculture. Trends Parasitol 31: 72-81 (2015).

This article is protected by copyright. All rights reserved. 
8 Hamre LA, Glover KA and Nilsen F, Establishment and characterization of salmon louse (Lepeophtheirus salmonis (Krøyer 1837)) laboratory strains. Parasitol Int 58: 251-460 (2009).

9 Thomassen JM, Hydrogen peroxide as a delousing agent for Atlantic salmon. In: Pathogens of wild and farmed fish: sea lice, ed. by Boxshall GA and Dafaye D, CRC Press, pp. 290-295 (1993).

10 Iversen M, Finstad B, McKinley RS, Eliassen RA, Carlsen KT and Evjen T, Stress responses in Atlantic salmon (Salmo salar L.) smolts during commercial well boat transports, and effects on survival after transfer to sea. Aquaculture 243: 272-382 (2004).

$11 \varnothing \mathrm{kt}$ forbruk av legemidler i norsk fiskeoppdrett. [Online] Norwegian National Health Institute (2017). Available: https://www.fhi.no/hn/legemiddelbruk/fisk/arkiv---okt-forbrukav-legemidler-i-/ [accessed 20 February 2017]

12 Johnson SC, Constible JM and Richard J, Laboratory investigations on the efficacy of hydrogen peroxide against the salmon louse Lepeophtheirus salmonis and its toxicological and histopathological effects on Atlantic salmon Salmo salar and Chinook salmon Oncorhynchus tshawytscha. Dis Aquat Org 17: 197-204 (1993).

13 Vera LM and Migaud $\mathrm{H}, \mathrm{Hydrogen}$ peroxide treatment in Atlantic salmon induces stress and detoxification response in a daily manner. Chronobiol Int 33(5): 530-542 (2016)

14 Burka JF, Fast MD and Revie CW, Lepeophtheirus salmonis and Caligus rogercresseyi, in Fish Parasites: Pathobiology and Protection, ed. by Woo PTK and Buchmann K, CABI International, United Kingdom, pp. 350-370 (2012).

This article is protected by copyright. All rights reserved. 
15 Marine Harvest: - Dødeligheten ved avulsing er dessverre alt for høy, [Online] Intrafish (2016). Available: http://www.intrafish.no/nyheter/776258/marine-harvest-dodelighetenved-avlusing-er-dessverre-alt-for-hoy [accessed 21 March 2017]

16 Helgesen KO, Romstad H, Aaen SM and Horsberg TE, First report of reduced sensitivity towards hydrogen peroxide found in the salmon louse Lepeophtheirus salmonis in Norway. Aquaculture Reports 1: 37-42 (2015).

17 Treasurer JW, Wadsworth S and Grant A, Resistance of sea lice Lepeophtheirus salmonis (Krøyer), to hydrogen peroxide on farmed Atlantic salmon, Salmo salar L. Aquac Res 31: $855-860$ (2000).

18 Samsing F, Johnsen I, Stien LH, Oppedal F, Albretsen J, Asplin L and Dempster T, Predicting the effectiveness of depth-based technologies to prevent salmon lice infection using a dispersal model. Prev Vet Med 129: 48-57 (2016).

19 Stien A, Bjørn PA, Heuch PA and Elston DA, Population dynamics of salmon lice Lepeophtheirus salmonis on Atlantic salmon and sea trout. Mar Ecol Prog Ser 290: 263-275 (2005).

20 Bowers JM, Speare DJ and Burka JF, The effects of hydrogen peroxide on the stress response of Atlantic Salmon (Salmo salar). J Vet Pharmacol Ther 25: 311-313 (2002).

21 Stien LH, Oppedal F and Kristiansen T, Dødelighetsstatistikk Lakseproduksjon I Sjø. Risikovurdering norsk fiskeoppdrett 2016 2: 130-133 (2016).

This article is protected by copyright. All rights reserved. 
22 Roth $\mathrm{M}$, The availability and use of chemotherapeutic sea lice control products. Contrib Zool 69: 109-118 (2000).

23 Leclercq E, Davie A and Migaud H, Delousing efficiency of farmed ballan wrasse (Labrus bergylta) against Lepeophtheirus salmonis infecting Atlantic Salmon (Salmo salar) postsmolts. Pest Manag Sci 70: 1274-1282 (2014).

24 Jones S. and Beamish R, Salmon lice: An Integrated Approach to Understanding Parasite Abundance and Distribution. John Wiley \& Sons, New Jersey (2011).

25 Skjervold PO, Fjæra SO, Østby PB and Einen O, Live-chilling and crowding stress before slaughter of Atlantic salmon (Salmo salar). Aquaculture 192: 265-280 (2001).

26 Stian MA, Aunsmo A and Horsberg TE, Impact of hydrogen peroxide on hatching ability of egg strings from salmon lice (Lepeophtheirus salmonis) in a field treatment and in a laboratory study with ascending concentrations. Aquaculture 422-423: 167-171 (2014).

27 Hutson KS, Ernst I and Whittington ID, Risk assessment for metazoan parasites of yellowtail kingfish Seriola lalandi (Perciformes: Carangidae) in South Australian sea-cage aquaculture. Aquaculture 271: 85-99 (2007).

28 Gaikowski MP, Rach JJ and Ramsay RT, Acute toxicity of hydrogen peroxide treatments to selected lifestages of cold-, cool-, and warmwater fish. Aquaculture 178: 191-207 (1999).

This article is protected by copyright. All rights reserved. 


\section{Tables}

Table 1: The initial ambient temperature and bath temperature combinations tested.

\begin{tabular}{|c|c|c|c|c|c|c|c|c|}
\cline { 2 - 9 } \multicolumn{1}{c|}{} & \multicolumn{8}{c|}{ Temperature $\left(^{\circ} \mathbf{C}\right.$ ) } \\
\hline Ambient & 16 & 16 & 16 & 13 & 13 & 13 & 10 & 10 \\
\hline Bath & 13 & 10 & 7 & 13 & 10 & 7 & 10 & 7 \\
\hline Treatment & $16-13-16$ & $16-10-16$ & $16-7-16$ & $13-13-13$ & $13-10-13$ & $13-7-13$ & $10-10-10$ & $10-7-10$ \\
\hline
\end{tabular}

This article is protected by copyright. All rights reserved. 


\section{Figures captions}

Figure 1: $\mathrm{H}_{2} \mathrm{O}_{2}$ use in Norwegian aquaculture in tonnes from 2009-2016. ${ }^{11}$

Figure 2: (A) Salmon mortality (\%) for each of the eight ambient temperature - bath temperature - ambient temperature treatments $(n=3)$. (B) Pre-adult lice remaining (\%) after each ambient temperature - bath temperature - ambient temperature treatment $(n=$ 3). Values are mean \pm S.E.

Figure 3: (A) Frequency (\%) of $\mathrm{H}_{2} \mathrm{O}_{2}$ treatments performed at bath temperatures from 4$17^{\circ} \mathrm{C}$ from 2012 - April 2017 in Norwegian salmon aquaculture ( $\left.n=545\right)$. (B) Frequency (\%) of $\mathrm{H}_{2} \mathrm{O}_{2}$ treatments performed during each month from January 2012 - April 2017 in Norwegian salmon aquaculture $(n=545)$. 


\section{University Library}

\section{- M M N E R VA A gateway to Melbourne's research publications}

Minerva Access is the Institutional Repository of The University of Melbourne

Author/s:

Overton, K;Samsing, F;Oppedal, F;Stien, LH;Dempster, T

Title:

Lowering treatment temperature reduces salmon mortality: a new way to treat with hydrogen peroxide in aquaculture

Date:

2018-03-01

Citation:

Overton, K., Samsing, F., Oppedal, F., Stien, L. H. \& Dempster, T. (2018). Lowering treatment temperature reduces salmon mortality: a new way to treat with hydrogen peroxide in aquaculture. PEST MANAGEMENT SCIENCE, 74 (3), pp.535-540. https://doi.org/10.1002/ ps. 4751 .

Persistent Link:

http://hdl.handle.net/11343/293860 